\title{
Neo-globalization Revisited: The Contours of a New Global Economic Order
}

Prof Dr M S S El Namaki

Dean, Victoria University, School of Management, Switzerland.

Founder / Dean (Retired) Maastricht School of Management, MSM, Netherlands.

\section{The problem}

Disruption induces disequilibrium. Today's global economy is the case in point. Powerful sources of disruption are undermining classic premises of global economic equilibrium and, in the process, changing the contours of the world economy. Long cherished globalization premises of free market, open economy, small government, private initiative, and deregulation are being challenged. Sources of this challenge are numerous. There are government and corporate debt, extreme individualism, high industry concentration, slanted income and wealth distribution, self-serving industry practices, and above all self-centered trade policies.

What has gone wrong and is there a way out of this dark environment is the focus of this article. The article addresses the need and premises of a Neo-globalization. It addressed, as a point of start, the failures of the existing paradigm and moves on to address premises for a Neo-globalization.

\section{The classic premises of globalization}

Globalization connotes the rapid enhancement of cross-border economic, social, technological exchange under conditions of capitalism.

There exists a notion that the roots of globalization lie within Reagan's economic policies of the early '80s. Reagan's economic policies rested, then, on some premises including small government and the reduction in government spending, reduction of marginal tax rates on income from both labor and capital, reducing regulation, and reducing inflation by controlling the growth of the money supply. Another element of this policy was the drive towards an external orientation of economies. He saw free-market values becoming the progressive ideal worth striving for while government interventionism was marked as a concept to be shunned. Reagan was an advocate of laissez-faire economics as he believed that a free market and capitalism provide the road to economic growth (Boskin, 1988).

A vast era of globalization emerged since those of Reagan's interventions and world markets

Available online at http://dx.doi.org/10.19085/sijbpg070501 
for goods, services, and capital has been rapidly integrating. China's economic rise occurred in parallel with these developments.

\section{Where did globalization go wrong?}

Globalization performed well if one is to go by key parameters as rates of increase of international trade as well as growth in key country GDPs over the past decades... Dents began to emerge, however. They showed in leading economies from the United States to Japan. The United States, the leading economy of the past decades, showed most of them. The following analysis addresses those flaws with the United States as a locus.

\section{Extreme individualism}

Extreme individualism constitutes anti-globalization forces. Extreme individualism is the belief that all actions are determined by, or take place for, the benefit of the individual, not the community society or country as a whole (Wolfe, 1976) (De Vries, 2019). Cultures in North America and Europe seem to be expressing a strong slant towards individualistic norms and values in stark contrast with globalization premises. A measure of individualistic bias is a Hofstede's index measuring the "degree to which people in a society are integrated into groups" or the emphasis on the "I" versus the "we". (Hofstede 2001). The following diagram illustrates some of his index findings.

\section{Figure (1) Hofstede's cultural dimensions theory: Comparison of 4 country indices.}

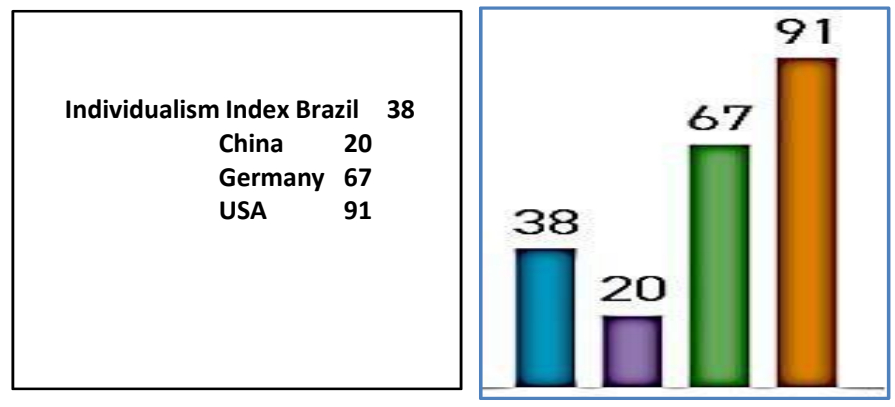

Source: Hofstede, 2001

Individualism is on the rise worldwide. Research findings show that increasing socioeconomic development is an especially strong predictor of increasing individualistic practices and values in a country over time. A 51-year analysis of data on individualist practices and values across 78 countries led to the conclusion that individualism is indeed rising in most of the societies tested. Specifically, statistical models indicated that individualism has increased by about $12 \%$ worldwide since 1960. (Henri C. Santos, Michael E. W. Varnum, Igor Grossmann, July 13, 2017).

Available online at http:/ /dx.doi.org/10.19085/sijbpg070501 


\section{Hostile trade policies}

Recent US trade policies maintained a perilous non-conducive protective pattern. This has undermined the spirit and the practice of globalization.

Trade restraining measures introduced by the US in the past year or two are in stark contrast with the free trade spirit of the past decades as much as the globalization policies that went with that. The goal of reducing the U.S. trade deficit and bringing manufacturing jobs back to the United States contradicted decades of US free-market policies and practices.

Trade restraining measures introduced by the US in the past year or two are in stark contrast with the free trade spirit of the past decades (Economist, Dec 5, 2019). Tariff confrontation with China seems to have had extreme capitalist ideology arguments at heart. The goal of reducing the U.S. trade deficit and bringing manufacturing jobs back to the United States contradicted decades of US free-market policies and practices. A change in China's allegedly unfair trade and technology practices would have required coordination with the EU and Japan as key trading partners as well as a resort to an existing global forum; the WTO. None of the projected positive consequences took place and the outcome is a negative impact on global trade volumes, industrial production, and capital formation (Bown and Irwin 2019),

U.S. grievances could have been handled within the WTO framework but US-WTO links were frayed. The United States has paralyzed WTO's Appellate Body, the Supreme Court for international trade, as replacement of two of three members became contentious. The outcome was an inability to issue rulings and a return to a post-war period of protectionism. All of that leaves a global trade policy and practice in tatters. And the only multilateral agency with the ability to act, losing influence.

Figure (4): Actual and scenarios for the flow of global trade until 2022.

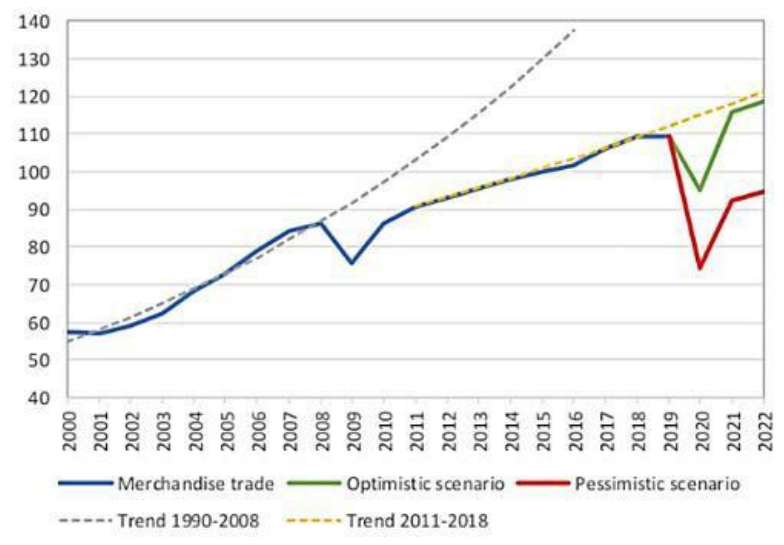

Source: WTO Secretariat. 


\section{Record corporate debt}

An increase in globalized business operations seems to have run, over the past decades, parallel to an alarming rise in corporate debt.

If one is to take the United States as a case, levels of US corporate debt have exceeded conceptual and operational norms and led to heavily indebted corporations operating under what have recently become precarious economic conditions. US overall debt accumulation since the 2008 financial crisis has been in the non-bank corporate sector where disruption and diminishing growth prospects imply lower-earning and greater difficulty in servicing debt.

The United States was not the only country demonstrating this flaw. US's financial corporate debt to GDP amounted to 73.9 percent in 2018 but several other countries have demonstrated an equal tendency too. Japan's corporate debt-to-GDP ratio amounted to $101.2 \%$ and the United Kingdom's corporate debt-to-GDP ratio amounted to $83.3 \%$ while South Korea's corporate debt-to-GDP ratio amounted to 101.2\%, all in 2018. (Wolf Street, March 23, 2019).

The rise in corporate debt levels constitutes a serious threat under current global economic constraints.

\section{Figure (3): USA mounting corporate debt (Non-financial corporate debt to GDP).}



Source: Wolfstreet, March 23, 2019

\section{Disrupted capital markets}

Structural deficiencies from high finance industry concentration to outdated institutional frameworks are undermining global capital market performance.

US investment banking industry is highly concentrated. Four firm concentration ratios for the investment banking and securities dealing industry amounted, according to an out of date U.S. Census Bureau's economic census figures, to $51.7 \%$ in 2007 (U.S. Census Bureau's economic census, 2012.). The United States credit rating system contributed, 
also, in no little way to capital market malperformance. Failure of structural finance is attributed, primarily, to the failure of the credit rating industry. The industry has misjudged the quality of many of the products that it rated, maintained a too familiar relationship with the companies it rated, filled a quasi-regulatory role, and made quasipolitical decisions rather than professional judgments. (El Namaki, 2014)

\section{Figure: (6) Shadow banking vs. traditional banking systems funds before and after the 2008 financial crisis}

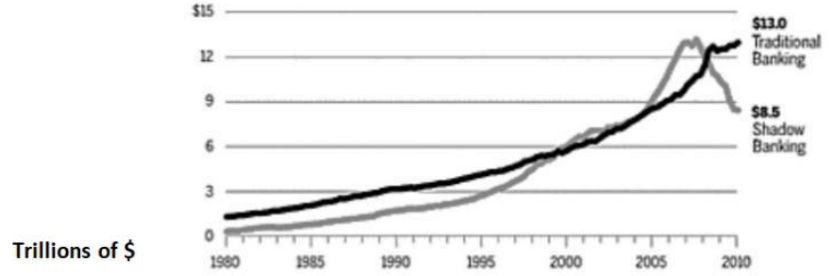

Source: Federal Reserve Flow of Funds Report. Wikipedia.

Figure (7) Mortgage-backed securities (MBS) credit rating downgrades, 2008.

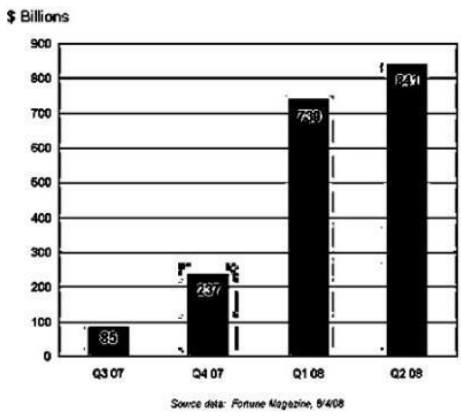

Source: Wikipedia.org/wiki/Credit_rating_agencies_and_the_subprime_crisis, 8 August 2008.

\section{High industry concentration}

A high level of industry and market concentration is restraining cross country trade flows and undermining globalization.

Concentration, or the combined market share of key industry operators, is a measure of competitive behavior. The level of concentration is measured by a concentration ratio of an aggregate of the market shares of the four key operators within the industry. There exists a common understanding that a $60 \%$ combined market share and above constitutes high concentration; US Industry concentration ratios have been reaching exceptional levels in the past decade. Concentration has become the prime business strategy among American firms. High technology and strategic industries have become the ultimate 
the domain of four or fewer corporations and that is to the detriment of consumers and workers... (Abdella, Oct 27, 2017).

Figure (2): Two firm concentration for selected industries in the USA in 2018.

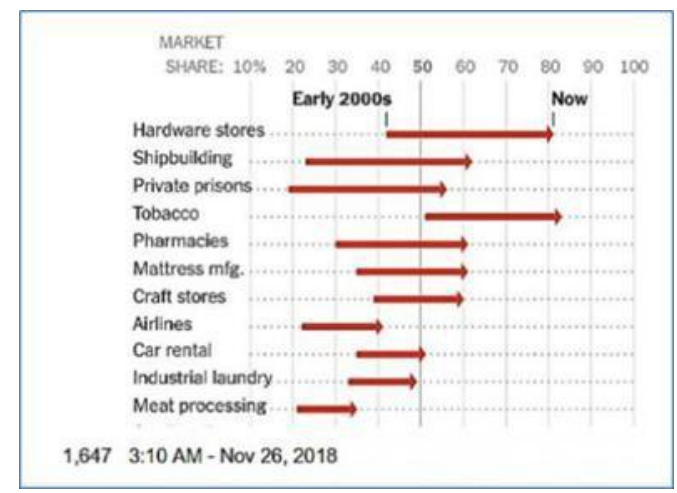

Source: America s monopoly problem, in one chart, Vex Nov 26, 2018

\section{Wealth and income disparities}

Wealth measures the value of all the assets of worth owned by an individual, a household, a community, or a country. Assets here include securities, property, metals, pension rights, etc. of that entity in question. Inequality of wealth distribution among constituents is a mark of extreme capitalism. Wealth is unequally distributed in several countries and the United States according to research findings is no exception. This inequality has grown considerably between 1989 and 2016 with the top 10\% of families ranked by household wealth (with at least $\$ 1.2$ million in net worth) owning $77 \%$ of the total wealth "volume". (Benmelech, 2019) (Kellog, 2019). A recent Rand study reveals that in the United States, if "distribution of income had remained the same as it was in the three decades following the Second World war, the bottom $90 \%$ would now be $\$ 47$ T richer "(Robert Reich, November 15, 2020).

Figure (9) Wealth shares by usual income group 1995-2016 in the USA

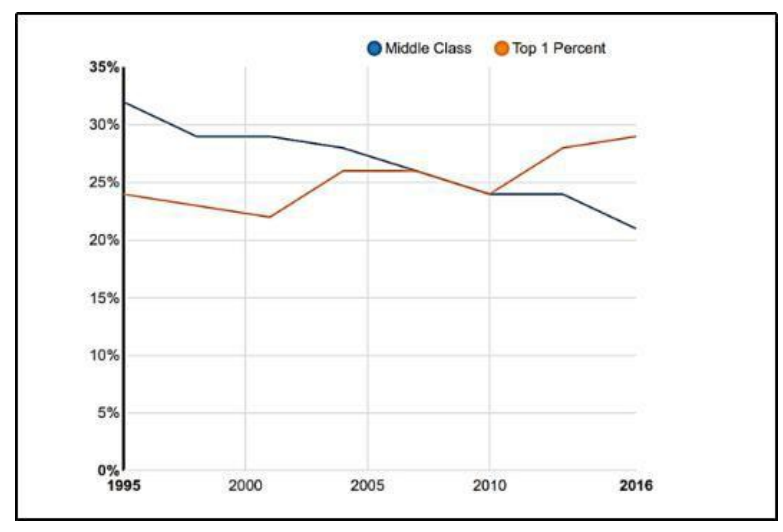

Source: Brookings. June 25, 2019. 


\section{Disruptive technologies}

Technologies that significantly alter the way that businesses or entire industries operate, could be disruptive and seem to be a leading source of constrained globalization.

Disruptive technologies leach potent forces that significantly alter existing products and processes and undermine flows of goods and services. Some recent disruptions have been as fast and complete as to destroy markets and even industries. They have created a shift in products, processes, and business models to what we may term the "new normal". (McKinsey, 2014). They have also created competitive advantages that the innovators tried to protect and showed reluctance to transfer across economic or geographical boundaries. Artificial intelligence, the internet of things, digitization, and several other present-day innovations are all examples of innovations that are largely confined to global operators and are effectively resorted to as instruments of national economic and political "war chest".(E1 Namaki,2018)

Technology sanctions belong to the myriad of sanctions imposed by countries on each other. The Chinese telecom company Huawei, the second-largest smartphone maker in the globe, has been banned from accessing parts of Google's Android mobile operating system by way of sanction. The Chinese telecom company ZTE was, by way of sanction too, blacklisted by the US government for a trade irregularity. The sanction wiped $\$ 3$ billion off ZTE's market value.

\section{How would the new norms of Neo-globalization look like?}

It is the author's contention that a new Neo-globalization paradigm is essential at this rather constrained phase of the global economy. This paradigm would deal with some of the abovementioned disruptions and add norms compatible with the myriad of contemporary and prospective shifts in key global performance parameters.

This new paradigm would include some or all of the following constituents.

\section{1. "Neo-industrial policies}

Free market systems are not substitutes for awareness of national priorities or the strategic pursuit of national goals. Rational industrial policies could fulfill this function.

Rational industrial policies could enhance globalization by ranking priorities and introducing the right trade, industry, and technology policy mix. Increasing domestic market freedom might also advance the non-utilitarian goal of securing the rights of citizens.

The issue of industrial policy is laced with ideology but nevertheless implemented in the United States. Resistance aside, the US government has been active in promoting specific industries into what amounts to a de facto industrial policy. President Obama's 2009 ARRA Act allowed for billions of federal grants and allocated tax credits to corporations in an attempt at boosting the energy industry. State and local subsidies were also extended, in his second term, to many corporations in an attempt to stimulate their industries. . The top recipients were Boeing (\$13.17billion), Alcoa ( $\$ 5.64$ billion), Intel ( $\$ 3.87$ billion), 
General Motors (\$3.49 billion) and Ford Motor Company( $\$ 2.52$ billion). (Stensrud, Oct 2016). United States recent resort to tariffs in order to reset trade relations with China is tantamount to putting trade policies at the mercy of industrial policies, however.

Industrial policies played a pre-eminent role in the development of several Asian countries including Japan. The Ministry of International Trade and Industry or MITI was one of the most powerful agencies of the Government of Japan as it effectively developed and ran much of Japanese industrial policy, funding research and directing investment and inducing a globalized role of the Japanese industry.

\section{Economic synergy}

Cross country synergy could provide the prime driving force of a globalized economy.

A state of cross-country synergy could emanate from present-day conditions and tomorrow's events and disruptions. Analysis of today's and tomorrow's driving forces of economies creates a framework for synergy-based globalized strategic behavior. The concept is represented in the following diagram where today's and tomorrow's driving forces of country A and country B are projected along a y and x-axis of a matrix.

Interaction between the two respective country driving forces produces synergies and leads to a synergy based strategic behavior. A strategic behavior that lies at the heart of a globalized economy.

Figure (1) the dynamic synergy concept

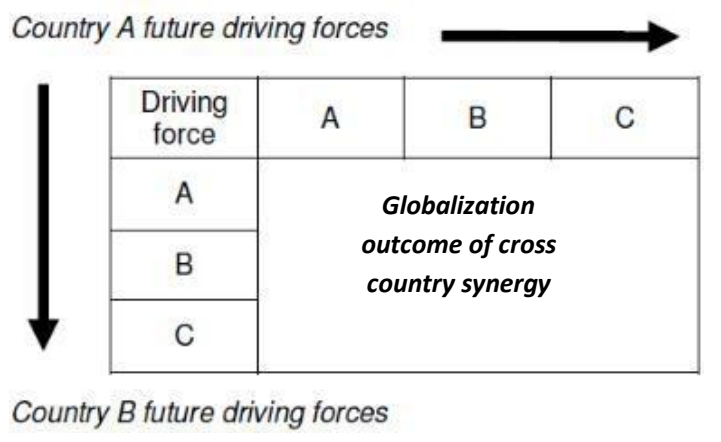

Source: El Namaki (2016)

China and Russia could provide a case here. China's future economic driving forces include the BRI or the Bridge and Road Initiative, a strong medium for the economic and possibly political link to central Asia as well as central Europe. This strong Chinese driving force congrues with Russia's expansion of the energy industry, the proliferation of the defense industry, and the restructuring of capital markets. (El Namaki, 2016; Fox, 2014; Seitz et al., 2015). A strong cross country synergy could very likely emerge from those driving forces (El Namaki, 2016). 


\section{Rational trade policies}

A sound trade policy built on a desire for synergy and an attempt at fair reciprocity could go a long way towards regaining the true spirit of globalization.

Creating new foundations for trade policies would require considerable political will. This willingness was there in the not too distant past. It is gaining new grounds with the recent conclusion of the RCEP, the Asia Pacific trade pact that will account for $50 \%$ of the World's population and about 30\% of global GDP. The United States opted out of this deal in 2017. A key feature of RCEB will be comprehensive market access and regional as well as a global approach to trade/

WTO's modus operandi and interaction with the United States need an overhaul. WTO rules allowed, for instance, a QUAD, or the group composed of The United States, Canada, Japan, and the European Union, to play an often disruptive role in matters of trade policies and trade disputes. Reform may start with a review of Quad's role in WTO policies, procedures, and ultimate decisions. Political clouds that shroud the composition of members of the jurisdictional organs of the organization is another source of friction.

Another critical issue is the need to endorse a genuine understanding of protectionism, a framework for a prudential resort to tariff and non-tariff trade barriers as well as a realization of the limits of trade policy instruments as war instruments. A vision of global opportunities and synergy should replace the current resort to terms as protection, national security, national interest, defense spending, technological superiority, etc.

Trade sanctions or unilateral and multilateral country penalties are also due for reform. In many an occasion sanction decisions are driven by politics and underlying geopolitical interests." Economic governance institutions are becoming either an arena for - or instruments in - that confrontation". (Russia Beyond. Sept 26, 2014).

\section{Restructuring capital markets}

Reforming capital markets is essential for a truly globalized flow of goods and services.

There is first the issue of country debts. The scope is wide but a sense of urgency is there if one is to consider how unsustainable some of those country debts are. There exists a serious need to introduce functional (not political) debt monitoring mechanisms that go beyond the distant assessment by sovereign credit rating agencies. A restructured IMF can perform this role given IMF's interventionist profile under conditions of country external imbalance.

Monitoring and control of corporate debt require sharpening of financial and securities exchange apparatus. Securitization played havoc with corporate debt generation and monitoring in the near past and it went on unchecked. Those institutions are assumed to exercise overall oversight but stronger measures and greater interventionist tools are called for.

Then there are the issues of securities from creation to trading. Prime among those is the

Available online at http://dx.doi.org/10.19085/sijbpg070501 
regulation of unregulated market operators as hedge funds and private equity operators, the introduction of safeguards into IPO access and conduct, the changing composition and policy reach of the FED system, and the reforming of structured finance instruments.

Central bank prerogative, instruments, and policy framework require an overhaul as well. Central banks should be ushered into a new era allowing serious monitoring of fiscal policies including government debt and interventionist emergency measures as quantitative easing. An expansion of central bank functions to include consumer and commercial banking should also be considered. (E1 Namaki).

\section{Technology sharing}

Neo-globalization should accommodate technology disruptions and build a framework for technology sharing.

Collaborative structures and other means of pooling and sharing technologies must be seriously explored. Patent pools, patent commons, open source innovation, open licensing arrangements, and non-assertion pledges or covenants are all possible venues. The benefits of pooling technologies from several sources outweigh any immediate advantage of constrained access. This has been the experience, for instance, with audio and video technologies involving a common standard, such as DVD and MPEG technology, where shared interests have led companies to form patent pools or joint licensing schemes.

Regulatory interventions including compulsory licenses or government authorizations requiring patented technology to be made available for certain public interests are modes of regulation.

Cross country cooperation is essential here as commercially and technically feasible technologies are rarely a stand-alone event. A product or a process might require multiparty efforts that combine breakthrough research, platform technologies, manufacturing know-how, and downstream flows. Laboratory efforts connote, mostly, finding the best way of combining input and building pathways to reach improved technologies. And this is mostly a cross-institution and cross country endeavor. (WIPO, March 2009)

\section{Infrastructure investment drive}

Infrastructure investment does propel a country's economic output and drives global economic exchange.

Infrastructure investments in energy, transport, communication, irrigation, and water supply raise productivity, reduce the cost of market access, and increase asset returns. It, more importantly perhaps, influences comparative advantage, enhances synergy, and stimulates global flows. Information and communications technology (ICT) infrastructure is, for instance, found to have positive trade effects for both exporters and importers in Asia (ADB, Dec 2015).

Infrastructure can also become a significant and lucrative recipient of investment inflows. Private investment in infrastructure networks, alongside or in place of state-owned operators, has been on the rise worldwide. Share of infrastructure in total inward FDI volume for individual countries ranged from less than 1\% in Israel to $20 \%$ in Spain and $28 \%$ 
in Turkey (OECD, 2013). China's BRI seems to endorse this principle. China's Bridge and Road Initiative is built around an infrastructure investment core with future investment envisaged in cross country roads, high-speed rails, power plants, pipelines, ports, airports, and telecommunications links. It is a prudent choice of an effective medium for economic growth and cross-country communication. Those investments will not only enhance all forms of exchange but also place China at the heart of a dynamic global economic framework

\section{Lower levels of market and industry concentration}

High market and industry concentration must be tempered if a measure of true globalization is to take place.

Laws once created in order to rein in the monopolies of the industrial age are failing to cope with the demands of the information age. This is especially the case in the United States. Most dominant technology corporations are a case in point. US congressional hearings as the one held on anti-trust violations by the most dominant technology corporations or Google, Apple, Facebook, and Amazon is a step in that direction. The intervention was based on the claims related to their products, marketing approaches, and strategic interventions. A Neo-globalization era would require US antitrust laws to extend to cover those once ignored technology operators and the related issues of big data, data technologies, data privacy, and data abuse. Action should be taken against the malignant practices of using power in one market to crush competitors in another, conducting unfair negotiations, infringing on small competitors' patents, giving monopoly returns precedence over the interest of business partners and consumers and amassing consumer data to the detriment of consumers. ( 6 reasons smaller companies want to break up Big Tech Jan 22, 2020, Vox)

Europe could probably provide an example here. Europe's resorts to antitrust laws have resulted in the levying of serious penalties against offending technology corporations. New laws are in the making too. The objective is to ease monitoring and make it easier for regulators to begin investigating the offending tech companies.

\section{Address income and wealth inequality.}

Reducing income inequalities carries the key to a friendlier, gentler neo-globalization.

A Myriad of measures has been suggested over the past decades. Many are obvious but many are concealed.

There is, first, the worn-out issue of tax reform. It goes without saying that a truly progressive tax rate could undermine income inequality. "The U.S. has a progressive tax system in name, but in practice, there are gaping loopholes. Closing up the loopholes, and taxing capital gains and dividend income as regular income is one of the more powerful tools society can use to fight income inequality". ("How to Solve Income Inequality", US News, Feb. 14, 2017)

Monitoring and regulating executive pay, in the United States again, is one of those. The gap between executive and labor pay in corporations has been measured and addressed in

Available online at http://dx.doi.org/10.19085/sijbpg070501 
many forums. Follow up was, however, limited. The Dodd-Frank Wall Street Reform Act required corporations to disclose employee pay in order to help shareholders better understand executive compensation practices and the resultant gap. Dodd-Frank reform measures should be revisited and reaffirmed.

Another measure is stimulating genuine entrepreneurship. Measures vary but among the basic is easing access to capital, extending credit, supporting business and technology upgrade.

There is also the bridging of the social capital gap. Social capital is the aggregate value of someone's social connections. Those with large social networks are more likely to tap into this network and synergize.

\section{Political empathy!}

Neo-globalization requires a high measure of political empathy or a degree of mutual understanding and reciprocal appreciation of goals and constraints.

Political empathy assumes an ability to identify with and understand the perspective, experiences and motivations of another party. And, also to comprehend and share attitudes, expressions and views of an opposite number. Demonizing those who hold different views is substituted by learning how to see them within a positive framework and express empathy despite the different perspectives. It is all in strong contrast with the "winner takes it all" culture with its concentration of rewards and waste of investment of past globalization decades (Washington Post, 2014). China's BRI seems to provide one of those rare cases where empathy is ingrained in the blueprints of the initiative.

Consider President Xi's statement " there's "no point" in blaming economic globalization for the world's problems, many of which have nothing to do with global trade" Also "BRI will serve as a new platform for all countries to achieve win-win cooperation ..." (January 17, 2017, NPR). And the statement by BRI heads of States "We stand for enhancing international cooperation including the Belt and Road Initiative and ... uphold the spirit of peace, cooperation, openness, transparency, inclusiveness, equality, mutual learning, mutual benefit and mutual respect" (Leaders Round Table of Belt and Road Forum, Beijing, 2017).

\section{The emerging model.}

The emerging neo globalization concept can best be represented viewed as a system within a systems theory framework. Input leads to a transformation process that, in its turn, leads to an output. The input is a country pertinent resource profile and terms of international exchange. Transformation is built around the variety of drivers of cross country exchange. Outputs, the ultimate product of the process, is value-added resulting from cross country economic, technological and cultural exchange. Future Neo-globalization processes are more likely to lead.

Available online at http:/ /dx.doi.org/10.19085/sijbpg070501 


\section{Summary and conclusions}

The concept of globalization as we once knew it is in bad need of a rewrite. Foundations established most notably during the Reagan era including free markets, open economies, small governments, deregulation, private initiative and corporate dominance are losing coherence. The ongoing shifts in economic policies and structures away from manufacturing and services towards disruptive technologies have hastened the blur.

Today's "globalization" is a hazy picture of what it is supposed to be. Challenges are posed by many forces from extreme individualism, hostile trade practices and high corporate debt to amorphous capital markets, disruptive technologies and escalating poverty. The emergence of a blatant substitute will require political courage, clear vision and genuine intent. For it will take fundamental measures to develop a neo globalization concept. A concept that will rationalize trade flows, undermine technology disruptions, endorse infrastructure investment, and reduce market and industry concentration among others.

\section{References}

[1]. M. Boskin, "Reagan and the economy: The successes, failures and unfinished agenda". ICS PR, Oct 1988

[2]. Wolfe, Tom, "The "Me" Decade and the Third Great Awakening". New York. New York: Condé Nast, 23 August 1976.

[3]. De Vries M, Have We Reached the Limit of Individualism? Knowledge, January 18, 2019

[4]. Hofstede, Geert (2001). Culture's Consequences: comparing values, behaviors, institutions, and organizations across nations (2nd Ed.). Thousand Oaks, CA: SAGE Publications

[5]. "Government fails to adequately address industry concentration", The Century Foundation, October 27, 2017

[6]. Abdella A, Steinebaum M, "The United States has a market concentration problem", Roosevelt Institute, Sept 2018

[7]. Amadeo K. "The US Debt and How It Got So Big", The Balance, Updated April 11, 2020)

[8]. "Sound and Fury, The Trump administration's trade policies clash with each other", The Economist, Dec 5, 2019.

[9]. Credit rating agency reform is incomplete, Brookings, March 6, 2017

[10]. Benmelech E, Bergman N, Kim H., "What is causing wage stagnation in America?, Kelloginsight, Dec 2, 2019

[11]. Chen X, Leeper E," US monetary and fiscal policies - conflict or cooperation? JEL, Jan 22, 2018

[12]. "The productivity pay gap", The Economic Policy Institute, July 2019

[13]. "US Trade offensive takes out WTO as global arbiter", Reuters,

[14]. "Our Economy Is a Sick Beast: The Corporate Debt Crisis Explained", Common Dreams, 28.03.2020. https://www.commondreams.org/views/2020/03/28/our- economy-sick-beast.

[15]. "What's Causing Wage Stagnation in America?" Kelloginsight, Dec 2, 2019.

[16]. Erin Duffin E, "U.S. household income distribution, by Gini-coefficient 1990- 2018", Statistica, Sept 24, 2019.

[17]. El Namaki, M. (2014). "How damaged are investment capital markets today". Competitiveness Review: An International Business Journal incorporating Journal of Global Competitiveness, 24(1), 51-58

[18]. "Credit rating agency reform is incomplete", Brookings, March 6, 2017.

[19]. "How credit rating agencies rule the world", the Guardian, 15 February 2012.

[20]. Xiaoshan Chen X, Leeper E., "US Monetary and Fiscal Policies - Conflict or Cooperation?" JEL, 22,.01.2018.

[21]. "Corporate Bond Market Trends, Emerging Risks and Monetary Policy", OECD, 18.02.2020.

[22]. Bordo M., Levy M.," Tariffs and monetary policy: A toxic mix ", Economic Policy Institute, 18.10 .2019

[23]. Sawhill I, Pulliam C, "Six facts about Wealth in the United States". Brookings, 25.06. 2019.

[24]. "Exploitative abuses, price gouging and covid 19: the cases pursued by EU and national 
competition authorities", Concurrences, April 3, 2020.

[25]. "What Wealth Inequality in America Looks Like: Key Facts \& Figures", Federal Reserve Bank St Luis, August 14, 2019.

[26]. "Top charts of 2019" Thirteen charts that clarify what our economic priorities need to be in 2020", Economic Policy Institute, December 23, 2019.

[27]. "Trade set to plunge as COVID-19 pandemic upends global economy", WTO, 8 April 2020.

[28]. "Corporate debt is in serious trouble - here's what it means if the market collapses", the conversation, March 28, 2020.

[29]. U.S. trade offensive takes out WTO as global arbiter - Reuters https://www.reuters.com/article/us-trade-wto/us-trade-offensive-takes-ou)

[30]. "America s monopoly problem, in one chart", Vox Nov 26, 2018.

[31]. "Top charts of 2019", Economic Policy Institute, December 23, 2019.

[32]. Amadeo K., "The US Debt and How It Got So Big", The Balance Updated April 11, 2020.

[33]. The Irish Times, World will need new financial system after Covid-19, March 25, 2020.

[34]. U.S. trade offensive takes out WTO as global arbiter - Reuters. https://www.reuters.com/article/us-trade-wto/us-trade-offensive-takes-ou)

[35]. The Economist, Sound and fury, The Trump administration's trade policies clash with each other, Dec 5, 2019.

[36]. Economic Policy Institute, the Productivity-Pay Gap, July 2019.

[37]. Bordo, M, and M Levy (2019), "Tariffs and Monetary Policy: A Toxic Mix", Shadow Open Market Committee, 27 September. Bordo, M, and R Hugh (1996).

[38]. US Monetary and Fiscal Policies - Convict or Cooperation? Xiaoshan Chen, Eric M. Leeper, JEL January 22, 2018.

[39]. The Balance, The US Debt and How It Got So Big, Kimberly Amadeo, Updated April 11, 2020.

[40]. Tariffs and monetary policy: A toxic mix Michael Bordon, Mickey Levy 18 October 2019.

[41]. Economic Policy Institute, Top charts of 2019Thirteen charts that clarify what our economic priorities need to be in 2020, December 23, 2019.

[42]. Benmelech E, Nittai K. Bergman, Hyunseob Kim "What's Causing Wage Stagnation in America?" Kelloginsight, Dec 2, 2019

[43]. . (WTO Trade set to plunge as COVID-19 pandemic upends global economy, 8 April 2020

[44]. The Street, Obama administration most aggressive ever in regulating $\mathrm{M}$ and A, April 28, 2016.

[45]. Is antitrust law keeping up? Fiona M. Scott Morton Yale Insights, July 12, 2013.

[46]. "How to Solve Income Inequality", US News, Feb. 14, 2017.

[47]. The Countries with the Most Monstrous Corporate Debt Pileups. Wolf Richter Wolf Street, Mar 23, 2019

[48]. El Namaki From Competitive Advantage to Cross-Country Dynamic Synergy, 2016 International Journal of Management and applied research

[49]. Psychological Science, the Association for Psychological Science, Global Increases in Individualism Henri C. Santos, Michael E. W. Varnum, Igor Grossmann, July 13, 2017),

[50]. National Research Council 1988. Globalization of Technology: International Perspectives. Washington, DC: The National Academies Press.

[51]. El Namaki M, "Disruption in Business Environments: A Framework and Case Evidence", International Journal of Management and Applied Research, Vol. 5, No. 1, pp. 1-7. https://doi.org/10.18646/2056.51.18-001

[52]. Industrial Policy in the United States, CIVITAS, Christian Stensrud, Oct 2016.

[53]. The sanctions war and the role of the WTO, Russia Beyond. Sept 26, 2014).

[54]. Sharing technology to meet a common challenge, WIPO, March 2009).

Disclaimer: The opinions \& analysis in the papers published in the journal are the personal views of the authors and SCHOLEDGE Publishing disclaims itself of any liability out of the same. 